\title{
Proteasome inhibitors decrease paclitaxel-induced cell death in nasopharyngeal carcinoma with the accumulation of CDK1/cyclin B1
}

\author{
LING HU ${ }^{1,2^{*}}$, XI PAN ${ }^{3 *}$, JINYUE HU ${ }^{1,2,4}$, HONG ZENG $^{5}$, XUETING LIU ${ }^{1,2}$, \\ MANLI JIANG $^{1,2}$ and BINYUAN JIANG ${ }^{1,2,4}$ \\ ${ }^{1}$ Medical Research Center, ${ }^{2}$ Changsha Cancer Institute, Changsha Central Hospital, University of South China, \\ Changsha, Hunan 410004; ${ }^{3}$ Department of Oncology, Third Xiangya Hospital, Central South University, \\ Changsha, Hunan 410013; ${ }^{4}$ Department of Clinical Laboratory, Changsha Central Hospital, University of South China, \\ Changsha, Hunan 410004; ${ }^{5}$ Reproductive Medicine Center, Foshan Maternal and Child Health Care Hospital, \\ Southern Medical University, Foshan, Guangdong 528000, P.R. China
}

Received March 25, 2021; Accepted July 2, 2021

DOI: $10.3892 /$ ijmm.2021.5026

\begin{abstract}
Southeast Asia is a region with high incidence of nasopharyngeal carcinoma (NPC). Paclitaxel is the mainstay for the treatment of advanced nasopharyngeal cancer. The present study investigated the effect of proteasome inhibitors on the therapeutic effect of paclitaxel and its related mechanism. The present data from Cell Counting Kit- 8 and flow cytometry assays demonstrated that appropriate concentrations of proteasome inhibitors (30 nM PS341 or $700 \mathrm{nM} \mathrm{MG132)} \mathrm{reduced} \mathrm{the}$ lethal effect of paclitaxel on the nasopharyngeal cancer cells. While $400 \mathrm{nM}$ paclitaxel effectively inhibited cell division and induced cell death, proteasome inhibitors (PS341 $30 \mathrm{nM}$ or MG132 $700 \mathrm{nM}$ ) could reverse these effects. Additionally, the western blotting results demonstrated accumulation of cell cycle regulation protein $\mathrm{CDK} 1$ and cyclin $\mathrm{B} 1$ in proteasome inhibitor-treated cells. In addition, proteasome inhibitors combined with paclitaxel led to decreased MCL1 apoptosis regulator, BCL2 family member/Caspase-9/poly (ADP-ribose) polymerase apoptosis signaling triggered by CDK1/cyclin B1. Therefore, dysfunction of CDK1/cyclin B1 could be defining the loss of paclitaxel lethality against cancer cells, a phenomenon affirmed by the CDK1 inhibitor Ro3306. Overall, the present results demonstrated that a combination of paclitaxel with proteasome inhibitors or CDK1 inhibitors is antagonistic to effective clinical management of NPC.
\end{abstract}

Correspondence to: Dr Binyuan Jiang, Medical Research Center, Changsha Central Hospital, University of South China, 161 Shaoshan South Road, Changsha, Hunan 410004, P.R. China

E-mail: jby2225859@126.com

${ }^{*}$ Contributed equally

Key words: paclitaxel, proteasome inhibitor, nasopharyngeal carcinoma, CDK1/cyclin B1

\section{Introduction}

Nasopharyngeal carcinoma (NPC) is highly prevalent in Southern China and Southeast Asia $(1,2)$. Advanced NPC is often associated with resistance to conventional radiotherapy and chemotherapy $(3,4)$. A combination chemotherapy regimen with different pharmacological mechanism drugs could be an effective strategy to enhance the therapeutic effect $(5,6)$. In the present study, proteasome inhibitor was combined with paclitaxel and their efficacy was evaluated in the treatment of NPC.

Bortezomib (PS341) is an inhibitor of the 26S proteasome, used in the treatment of multiple myeloma, as well as in clinical trials for solid tumors as a single agent or in combination with other drugs (7-9). Proteasome inhibition causes rapid accumulation of ubiquitinated proteins and perturbation of protein metabolism, leading to initiation of apoptosis by the endoplasmic reticulum to overcome irreversible cellular damage $(10,11)$. The ubiquitin-proteasome system is a non-lysosomal protein degradation pathway, which regulates numerous eukaryotic cell signaling pathways, including the cell cycle (12). In the cell cycle pathway, two families of E3 ubiquitin ligases, anaphase promoting complex or cyclosome (APC/C) and Skp1/CUL1/F-box protein, are responsible for periodic proteolysis of cell cycle regulators, ensuring regulated cell cycle progression (13).

On the other hand, paclitaxel is a member of the taxane class of drugs, used as an anti-microtubule agent in the treatment of cancer, including NPC (14). Binding of paclitaxel to $\beta$-tubulin dimers inhibits the hydrolysis of GTP, resulting in microtubule stabilization and loss of dynamics (15). Dysfunction of microtubules causes incorrect spindle-chromosome attachment and prolonged mitotic arrest, resulting in mitotic catastrophe, and initiation of cell death to prevent transmission of erroneous genetic information $(16,17)$.

Mitotic catastrophe refers to cell death associated with inappropriate mitosis or irreversible cell cycle arrest (18). Cells that undergo mitotic catastrophe are morphologically distinguishable, since nuclear envelopes form around individual or 
groups of chromosomes, resulting in large nonviable cells with multiple micronuclei $(19,20)$. Mitotic catastrophe has been proposed to be a tumor suppression mechanism, while evasion of mitotic catastrophe constitutes one of the mechanisms of cancer development (21). Cells typically undergo prolonged mitotic arrest when treated with antimitotic drugs, and the cell fate is determined by assessing the slow or sudden degradation of cyclin B1 resulting in mitotic slippage or activation of cell death pathways, respectively (22). The activation of cell death pathways leads to accumulation of death activators or loss of death inhibitors (23). Additionally, mitotic cell death results from intracellular signals breaching the death threshold before achieving the mitotic slippage threshold (24).

The CDK1/cyclin B1 complex is essential for cell cycle progression in eukaryotes. Cyclin B1 is a regulatory subunit, while CDK1 is a catalytic subunit (25). CDK1 phosphorylates a number of mitotic substrates, which are involved in mitotic spindle generation, chromosome condensation, nuclear envelope breakdown and mitotic death (26). Accumulation of the CDK1-cyclin B1 proteins is critical for the activation of CDK1 and entry of mitosis (27). In addition to cyclin B1 binding, CDK1 activation requires the phosphorylation at T161 of its activation segment and the dephosphorylation of Y15 and T14 residues (28). After mitosis, destruction of cyclin B1 provides a mechanism to rapidly inactivate CDK1 and exit mitosis, and CDK1/cyclin B1 catalyzes its own destruction by stimulating the activity of $\mathrm{APC} / \mathrm{C}^{\mathrm{CDC} 20}(29)$. When cells undergo inappropriate mitosis or irreversible cell cycle arrest after treatment with antimitotic drugs, the mitotic cells also require the sudden degradation of CDK1/cyclin B1 and the breaching of the death threshold $(30,31)$.

In the present study examined the combination chemotherapy regimen, and revealed that proteasome inhibitor PS341 markedly decreased the number of rounded cells in paclitaxel-treated NPC. Accordingly, the present study aimed to investigate the effect of proteasome inhibitor in attenuating the lethality of paclitaxel against NPC cells and to explore its related molecular mechanism.

\section{Materials and methods}

Cell culture and drugs. The 5-8F and 6-10B NPC cell lines (Cancer Center of Sun Yat-sen University, Guangzhou, China) used in the present study were cultured in DMEM (Biological Industries) with 10\% FBS (Biological Industries), penicillin (100 U/ml; Biological Industries) and streptomycin (100 $\mu \mathrm{g} / \mathrm{ml}$; Biological Industries) in a humidified incubator with $5 \% \mathrm{CO}_{2}$ at $37^{\circ} \mathrm{C}$. Paclitaxel, PS341, MG132, Ro3306 and cycloheximide were purchased from MedChemExpress. Flutax1 was purchased from R\&D Systems, Inc. The cells were cultured with paclitaxel $(400 \mathrm{nM})$, flutax1 (3 $\mu \mathrm{M})$, PS341 (30 nM), MG132 (700 nM), Ro3306 $(5 \mu \mathrm{M})$ or cycloheximide $(1 \mu \mathrm{g} / \mathrm{ml})$ in a humidified incubator with $5 \% \mathrm{CO}_{2}$ at $37^{\circ} \mathrm{C}$ for 24 or $48 \mathrm{~h}$ during the test. In addition, the sets and procedure of the cycloheximide assay (Fig. S1) were as follows: Two sets were cycloheximide-treated cells and non-cycloheximide-treated cells, and each set contained four groups: NC (0.5\%, v/v, DMSO), PTX (400 nM), PS341 (30 nM) and PTX (400 nM)-PS341 (30 nM). Cycloheximide-treated cells were cultured as groups for $16 \mathrm{~h}$, then cycloheximide $(1 \mu \mathrm{g} / \mathrm{ml})$ was added for a further 8-h treatment, and cells were harvested at $24 \mathrm{~h}$. While non-cycloheximide-treated cells were cultured as groups and harvested at $24 \mathrm{~h}$. The used drug concentrations were tested against $5-8 \mathrm{~F}$ and $6-10 \mathrm{~B}$ cells in the present study based on the following principles: Paclitaxel and flutax1 were used at a lethal concentration, and PS341, MG132, Ro3306 and cycloheximide were used at low toxicity concentrations or nontoxic concentrations, ensuring cell proliferation inhibition and death were mainly caused by taxol analogues. After cell attachment, taxol-analogues and PS341, MG132 or Ro3306 were added simultaneously.

Cell Counting Kit-8 (CCK-8) assay. To examine the effect on cell proliferation, 15,000 cells per well were seeded in a 96-well plate in DMEM with 10\% FBS ( $n=3)$. After cell adhesion, the medium was replaced with a fresh complete medium containing drugs at the corresponding concentrations as follow: Negative control (NC; 0.5\%, v/v, DMSO), PTX (400 nM),PS341 (30 nM), PTX (400 nM)-PS341 (30 nM), MG132 (700 nM), PTX (400 nM)-MG132 (700 nM), PTX (400 nM)-PS341 (0, 5, 10, 25, 50 or $100 \mathrm{nM})$, PTX (400 nM)-MG132 (0, 50, 100, 200, 400 or $700 \mathrm{nM})$, Ro3306 (5 $\mu \mathrm{M})$ or PTX (400 nM)-Ro3306 $(5 \mu \mathrm{M})$. A total of $10 \mu \mathrm{l} \mathrm{CCK}-8$ reagent (Shanghai Yeasen Biotechnology Co., Ltd.) was added to each well every $24 \mathrm{~h}$ for 2 days. The cells were incubated for $1 \mathrm{~h}$ and then absorbance at $450 \mathrm{~nm}$ was measured using a microplate reader (ELx800; BioTek Instruments, Inc.).

Western blotting. To examine the related protein expression changes, $5 \times 10^{5}$ cells per well were seeded in a 12 -well plate with DMEM with $10 \%$ FBS. After cell culture in a humidified incubator with $5 \% \mathrm{CO}_{2}$ at $37^{\circ} \mathrm{C}$ for cell adhesion, the medium was replaced with a fresh complete medium containing drugs at the corresponding concentrations as follows: Negative control (NC; 0.5\%, v/v, DMSO), PTX (400 nM), PS341 (30 nM), PTX (400 nM)-PS341 (30 nM), MG132 (700 nM), PTX (400 nM)-MG132 (700 nM), Ro3306 (5 $\mu \mathrm{M})$ or PTX (400 nM)-Ro3306 (5 $\mu \mathrm{M})$. After 24 or $48 \mathrm{~h}$, cells were harvested and lysed in Cell lysis buffer for Western and IP (Beyotime Institute of Biotechnology). The BCA Protein Assay kit (Beyotime Institute of Biotechnology) was selected for protein concentration determination. A total of $20 \mu \mathrm{g}$ total proteins were loaded per lane and resolved by $10 \%$ SDS-PAGE, and then transferred onto a $0.45-\mu \mathrm{m}$ PVDF membrane (MilliporeSigma), except p21 Waf1/Cip1 which was transferred onto a $0.22-\mu \mathrm{m}$ PVDF membrane(MilliporeSigma). The membrane was blocked in PBS with $0.05 \%$ Tween-20 (PBST) with 5\% w/v nonfat dry milk at room temperature for $1 \mathrm{~h}$, then washed three times in PBST for 2 min each at room temperature, followed by incubation with primary antibody in PBST with gentle agitation at $4^{\circ} \mathrm{C}$ overnight. The membrane was washed three times for $10 \mathrm{~min}$ each in PBST and then incubated with an HRP-conjugated secondary antibody at room temperature for $60 \mathrm{~min}$ in PBST. After three washes for 5 min each in PBST, the signal was visualized using an ECL detection reagent (Thermo Fisher Scientific, Inc.) and imaged. Ubiquitin antibody (cat. no. 3933; dilution, 1:1,000), CDK1 antibody (cat. no. 77055; dilution, 1:1,000), phosphorylated (p-)CDK1(Thr14) antibody (cat. no. 2543; dilution, 1:1,000), p-CDK1(Thr161) antibody (cat. no. 9114; dilution, 1:1,000), p21 Waf1/Cip1 antibody (cat. no. 2947; dilution, 
1:1,000), MCL1 apoptosis regulator, BCL2 family member (MCL1) antibody (cat. no. 94296; dilution, 1:1,000), caspase-9 antibody (for detection of procaspase-9 and cleaved caspase-9; cat. no. 9502; dilution, 1:1,000), poly (ADP-ribose) polymerase (PARP) antibody (for detection of full-length PARP and cleaved PARP; cat. no. 9532; dilution, 1:1,000) were purchased from Cell Signaling Technology, Inc. Cyclin D1 (cat. no. AF1183; dilution, 1:1,000), cyclin E1 (cat. no. AF2491; dilution, 1:1,000), cyclin A2 (cat. no. AF2524; dilution, 1:1,000), cyclin B1 (cat. no. AF6627; dilution, 1:1,000), aurora A (cat. no. AF1708; dilution, 1:1,000), aurora B (cat. no. AF1930; dilution, 1:1,000) and GAPDH (cat. no. AF0006; dilution, 1:2,000) primary antibodies were purchased from Beyotime Institute of Biotechnology. GAPDH was used as a control. The secondary antibodies, including anti-rabbit IgG, HRP-linked antibody (cat. no. 7074; dilution, 1:2,000) and anti-mouse IgG, HRP-linked antibody (cat. no. 7076; dilution, 1:2,000), were purchased from Cell Signaling Technology, Inc. Grayscale semi-quantifications of bands was performed using ImageJ software (version 1.42q; National Institutes of Health). GAPDH was used as a loading control for total protein, the grayscale values of each protein band were normalized to GAPDH within groups, and relative protein levels were normalized to the control group.

Cell microscopic observation. To examine the paclitaxel-induced cell morphology changes, $3 \times 10^{5}$ cells per well were seeded in a 24-well plate with DMEM with $10 \%$ FBS. After cell culture in a humidified incubator with $5 \% \mathrm{CO}_{2}$ at $37^{\circ} \mathrm{C}$ for cell adhesion, the medium was replaced with a fresh complete medium containing drugs at the corresponding concentrations as follows: NC $(0.5 \% \mathrm{v} / \mathrm{v}$ DMSO $)$, PTX (400 nM), PS341 (30 nM), PTX (400 nM)-PS341 (30 nM), MG132 (700 nM), PTX (400 nM)-MG132 (700 nM). After culture in a humidified incubator with $5 \% \mathrm{CO}_{2}$ at $37^{\circ} \mathrm{C}$ for $24 \mathrm{~h}$, the cells were observed under a Leica DM IL LED inverted light microscope (Leica Microsystems, Inc.) and images were captured. The ratio of rounded cells to total cells in five random fields of vision (magnification, x200) was counted. To examine the paclitaxel-induced nuclear condensation in NPC cells, Hoechst 33342 Staining Solution for Live Cells 100X (cat. no. C1028; Beyotime Institute of Biotechnology) was used to stain the nucleus. After removing the medium and rinsing with PBS, nuclei were stained with $200 \mu$ l diluted Hoechst 33342 (dilution, 1:100) per well for $10 \mathrm{~min}$ at $37^{\circ} \mathrm{C}$, rinsed three times with PBS and observed under a fluorescence microscope (Leica Microsystems, Inc.). Merging of the images was performed using ImageJ software (version 1.42q; National Institutes of Health). To examine the taxol-induced microtubule changes, fluorescently labeled taxol flutax1 (R\&D Systems, Inc.) was used for tracing taxol in NPC cells, while the transformation of microtubules in flutax1-treated NPC cells was observed using Tubulin-Tracker Red (cat. no. C1050; Beyotime Institute of Biotechnology). After culture with flutax1 $(3 \mu \mathrm{M})$, flutax1 (3 $\mu \mathrm{M})-\mathrm{PS} 341(30 \mathrm{nM})$ and flutax1 (3 $\mu \mathrm{M})-\mathrm{MG} 132$ $(700 \mathrm{nM})$ in a humidified incubator with $5 \% \mathrm{CO}_{2}$ at $37^{\circ} \mathrm{C}$ for $24 \mathrm{~h}$, cells were rinsed with PBS two times and fixed with $3.7 \%$ paraformaldehyde (Sigma-Aldrich; Merck KGaA) in PBS for $20 \mathrm{~min}$ at room temperature. Subsequently, cells were washed three times with PBS containing $0.1 \%$ Triton X-100 for 5 min each time at room temperature. Tubulin-Tracker Red was diluted with PBS containing 3\% BSA (Beyotime Institute of Biotechnology) and 0.1\% Triton X-100 (Beyotime Institute of Biotechnology), and $200 \mu 1$ Tubulin-Tracker Red (dilution, 1:100) was added to each well for $60 \mathrm{~min}$ at room temperature, followed by counterstaining with $200 \mu \mathrm{l}$ diluted Hoechst 33342 (dilution, 1:100) per well for $10 \mathrm{~min}$ at $37^{\circ} \mathrm{C}$. After three washes with PBS for 5 min each at room temperature, related results were visualized with a fluorescence microscope (Lionheart; BioTek Instruments, Inc.).

Cell cycle detection. To investigate the cell cycle distribution, $2.5 \times 10^{6}$ cells per well were seeded in a 6-well plate with DMEM with $10 \%$ FBS ( $n=3)$. After cell adhesion, the medium was replaced with fresh complete medium containing drugs at the corresponding concentrations as follows: $\mathrm{NC}(0.5 \% \mathrm{v} / \mathrm{v}$ DMSO), PTX (400 nM), PS341 (30 nM), PTX (400 nM)-PS341 (30 nM), MG132 (700 nM), PTX (400 nM)-MG132 (700 nM), $\operatorname{Ro3306}(5 \mu \mathrm{M})$ and PTX (400 $\mathrm{nM})-\operatorname{Ro3306}(5 \mu \mathrm{M})$. After culture in a humidified incubator with $5 \% \mathrm{CO}_{2}$ at $37^{\circ} \mathrm{C}$ for $24 \mathrm{~h}$, the cells were harvested and fixed in $75 \%$ alcohol at $4^{\circ} \mathrm{C}$. After $24 \mathrm{~h}, 75 \%$ alcohol was removed by centrifugation at $500 \mathrm{x} \mathrm{g}$ at $4^{\circ} \mathrm{C}$ for $5 \mathrm{~min}$, followed by two washes with cold PBS. Cells were stained using propidium iodide (PI final concentration, $50 \mu \mathrm{g} / \mathrm{ml}$; Beyotime Institute of Biotechnology) and RNase treatment (RNase final concentration, $100 \mu \mathrm{g} / \mathrm{ml}$; Beyotime Institute of Biotechnology), and incubated for $20 \mathrm{~min}$ at $37^{\circ} \mathrm{C}$ in the dark. The cell cycle distribution was determined by evaluating DNA content using a BD Accuri C6 Flow Cytometer (BD Biosciences), and the data were analyzed using the BD Accuri C6 Software (version 1.0.264.21; BD Biosciences). The $\mathrm{NC}$ group was set as the control when comparing $\mathrm{SubG}_{1}$ phase change, PTX (400 nM) group was set as the control when comparing restored $\mathrm{G}_{1}$ phase and decreased $\mathrm{G}_{2} / \mathrm{M}$ phase.

Cell apoptosis detection. The cell apoptosis assay was performed using the Annexin V-FITC/PI Apoptosis Detection kit (Shanghai Yeasen Biotechnology Co., Ltd.) according to the manufacturer's protocol. Briefly, $1.5 \times 10^{6}$ cells per well were seeded in a 6-well plate with DMEM with $10 \%$ FBS $(n=3)$. After cell adhesion, the medium was replaced with fresh complete medium containing drugs at the corresponding concentrations as follows: NC (0.5\% v/v DMSO), PTX (400 nM), PS341 (30 nM), PTX (400 nM)-PS341 (30 nM), MG132 (700 nM), PTX (400 nM)-MG132 (700 nM), Ro3306 $(5 \mu \mathrm{M})$ and PTX $(400 \mathrm{nM})-\operatorname{Ro} 3306(5 \mu \mathrm{M})$. After culture in a humidified incubator with $5 \% \mathrm{CO}_{2}$ at $37^{\circ} \mathrm{C}$ for $48 \mathrm{~h}$, the cells were harvested by centrifugation at $500 \mathrm{x} \mathrm{g}$ at $4^{\circ} \mathrm{C}$ for 5 min and washed twice with cold PBS, then resuspended in $1 \mathrm{X}$ binding buffer at a concentration of $5 \times 10^{5}$ cells $/ \mathrm{ml}$. Cells (100 $\mu \mathrm{l})$ were resuspended with $5 \mu \mathrm{l}$ Annexin V-FITC and $10 \mu \mathrm{l}$ PI. After incubation for $15 \mathrm{~min}$ at room temperature in the dark, $400 \mu 1 \mathrm{1X}$ Binding Buffer was added to each tube. The proportion of apoptotic cells was measured using a BD Accuri C6 Flow Cytometer (BD Biosciences) within $1 \mathrm{~h}$, and data were analyzed using the BD Accuri C6 Software (version 1.0.264.21; BD Biosciences). Annexin V-FITC and PI double-positive cells were considered to be late apoptotic cells, while Annexin V-FITC positive and PI-negative cells were considered to be early apoptotic cells. The fold changes in the percentage of apoptotic cells were calculated, and each group 
was normalized to the NC group. The NC group was set as the control when comparing fold change of paclitaxel-induced apoptosis, and the PTX (400 nM) group was set as the control when comparing fold change of proteasome inhibitors or Ro3306 decreased paclitaxel-induced apoptosis. All fold change data were normalized to the NC group.

Statistical analysis. All experiments were performed at least in triplicate and data are presented as the mean \pm SD. Data were analyzed using one-way ANOVA or two-way ANOVA with multiple comparison as Tukey's post hoc test or Dunnett's post hoc test as appropriate. Figures were generated and statistical analysis was performed using GraphPad Prism 8.3.0 (GraphPad Software, Inc.). $\mathrm{P}<0.05$ was considered to indicate a statistically significant difference.

\section{Results}

Proteasome inhibitors reduce the paclitaxel-specific inhibition of NPC cell proliferation. A CCK-8 assay was performed to determine the inhibition of NPC cell proliferation by proteasome blockers. The present results demonstrated that $5-8 \mathrm{~F}$ cells and $6-10 \mathrm{~B}$ cells were still growing after culture with proteasome inhibitor PS341 (30 nM) or MG132 (700 nM) after $48 \mathrm{~h}$. Additionally, both inhibitors reduced the inhibitory effect of paclitaxel on NPC cell proliferation after $48 \mathrm{~h}$, while paclitaxel $(400 \mathrm{nM})$ was toxic to $5-8 \mathrm{~F}$ and $6-10 \mathrm{~B}$ cells based on the decreased absorbance values at $48 \mathrm{~h}$ (Fig. 1A and B). Accumulation of ubiquitinated-proteins indicated compromised proteasome functions following treatment with PS341 (30 nM) and MG132 (700 nM) after $24 \mathrm{~h}$ (Fig. 1C). In addition, the linear plot of CCK-8 results revealed increasing absorbance values at $450 \mathrm{~nm}$ with the gradual increase in concentrations of proteasome inhibitors compared with the negative control group (PTX $400 \mathrm{nM})$. PS341 (10-100 nM) and MG132 (50-700 $\mathrm{nM})$ attenuated the inhibitory effect of paclitaxel (400 nM) on cell proliferation after $48 \mathrm{~h}$ (Fig. 1D). Therefore, proteasome inhibition was associated with reduced lethality of paclitaxel.

Proteasome inhibitors reduce paclitaxel-specific morphological changes in NPC cells. Paclitaxel-induced mitotic catastrophe often leads to changes in cell morphology and chromatin condensation after $24 \mathrm{~h}$ (31). The present findings demonstrated that proteasome inhibitors markedly reduced the paclitaxel-specific morphological changes and multiple micronuclei of NPC cells after $24 \mathrm{~h}$ (Fig. 2A-D). Representative images (magnification, $\mathrm{x} 40$; top rows in Fig. 2A and B) revealed that most of the paclitaxel-treated cells were rounded; however, rounded cells decreased when the cells were treated with paclitaxel and proteasome inhibitors (PS341 or MG132) synchronously. The ratio of rounded cells and total cells in five random fields of vision (magnification, x200; bottom row in Fig. 2A and B) was determined. The results of statistical analyses indicated that proteasome inhibitors significantly decreased paclitaxel-induced rounded cells. These data demonstrated that the proteasome inhibitors aided the NPC cells in evading mitotic catastrophe after $24 \mathrm{~h}$, speculated that more NPC cells survived with spindle-chromosome attachment errors represented higher chromosome mutation risk.
Proteasome inhibitors decrease the paclitaxel-induced cell cycle arrest in NPC cells. To determine the cell cycle profile in the drug-treated NPC cells after $24 \mathrm{~h}$, the DNA content was evaluated using flow cytometry. Compared with NC groups, addition of paclitaxel increased the percentage of Sub $\mathrm{G}_{1}$ phase cells in the PTX (400 nM), PTX (400 nM)-PS341 (30 nM) and PTX (400 nM)-MG132 (700 nM) groups. Paclitaxel blocked almost all NPC cells at the $\mathrm{G}_{2} / \mathrm{M}$ phase; however, when the cells were treated with paclitaxel and proteasome inhibitors (PS341 or MG132) synchronously, the $G_{1}$ phase was significantly restored and $\mathrm{G}_{2} / \mathrm{M}$ phase was significantly decreased compared with the paclitaxel-treated group (Fig. 3A). These results combined with the CCK-8 assay data (Fig. 1A and B) suggested that proteasome inhibitors could help NPC cells in escaping paclitaxel-induced mitotic arrest and proliferation inhibition.

Proteasome inhibitors reduce paclitaxel-induced cell death in NPC cells. Apoptosis is the main outcome of mitotic catastrophe-induced cell death (32). An Annexin V-FITC/PI assay was performed to determine the effect of paclitaxel coupled with proteasome inhibitors on cell apoptosis after $48 \mathrm{~h}$. Compared with the NC groups, addition of paclitaxel in the PTX (400 nM), PTX (400 nM)-PS341 (30 nM) and PTX (400 nM)-MG132 (700 nM) groups increased the percentage of apoptotic cells. When the cells were treated with paclitaxel and proteasome inhibitors (PS341 or MG132) synchronously, the percentage of apoptotic cells was significantly decreased compared with that in the paclitaxel-treated group. The data demonstrated a marked reduction of paclitaxel-induced apoptosis in NPC cells by the proteasome inhibitors (Fig. 3B).

Proteasome inhibitors lead to an enlarged microtubule cytoskeleton system and freed nuclear condensation of NPC cells treated with flutaxl. Furthermore, the present study used fluorescently labeled taxol flutax1 (green) to treat NPC cells, tubulin-tracker (red) to label microtubules, and hoechst 33342 (blue) to stain DNA to extract more data from microtubule stabilized cells. In the Flutax $1(3 \mu \mathrm{M})$ group, most of the flutax1-treated NPC cells (green) presented multiple micronuclei (blue) after $24 \mathrm{~h}$, and pyknotic microtubules (red) wrapped with these condensed genetic materials (Fig. 4A; first and fourth row). Condensed microtubules and chromatin indicated that the mitotic spindle failed in separating chromosomes to their respective poles, and most NPC cells were stuck in the mitosis phase for taxol-treatment (33). Notably, a combination of flutax 1 and proteasome inhibitors (PS341 or MG132) led to an enlarged microtubule cytoskeleton system and fewer multiple micronuclei in NPC cells, and also fewer NPC cells were stuck in the mitosis phase (Fig. 4A).

Proteasome inhibitors alter the expression pattern of the CDK1/cyclin B1 protein in NPC cells. There are four main types of cyclin in human cells, cyclin D1 (protein exists throughout the cell cycle, triggers cell from $G_{0}$ to $G_{1}$ and $G_{1}$ to $S$ phase), cyclin E1 (protein mainly exists during $G_{1} / S$ phase, preparing for DNA replication in $\mathrm{S}$ phase), cyclin A2 (protein mainly exists during $\mathrm{G}_{2} / \mathrm{M}$ transition, for the activation of DNA replication in $\mathrm{S}$ phase) and cyclin B1 (protein mainly exists during $\mathrm{G}_{2} / \mathrm{M}$ phase, for the assembly of mitotic spindle and mitosis promotion) $(34,35)$. In the present study, 
A

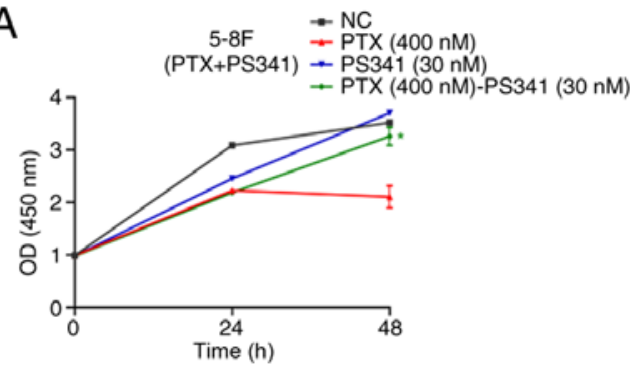

B

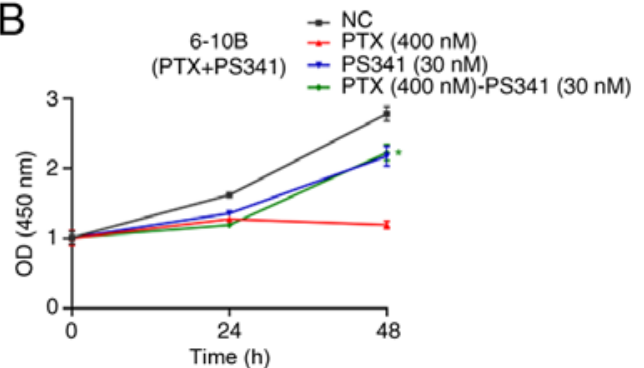

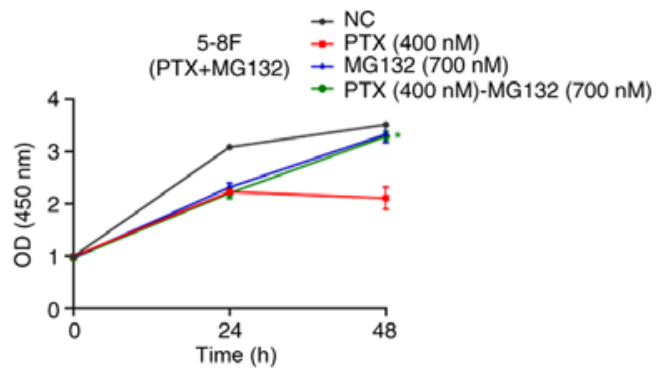

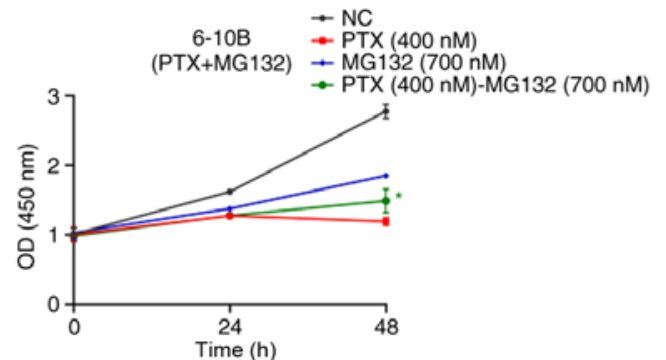

\section{C}
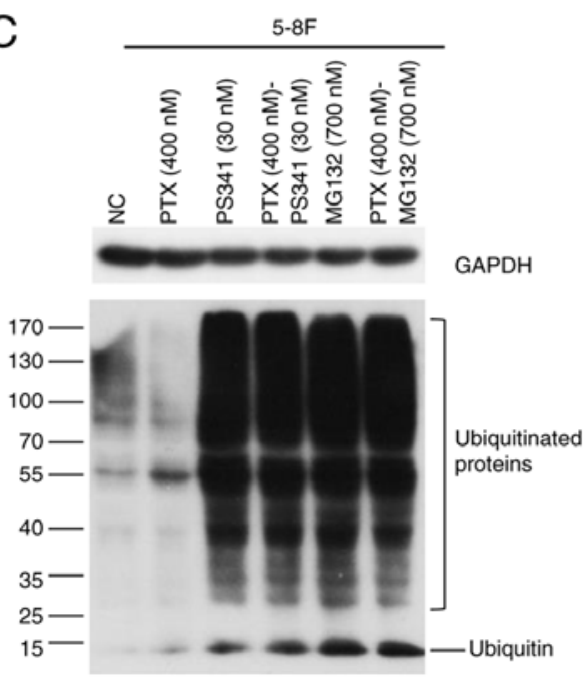
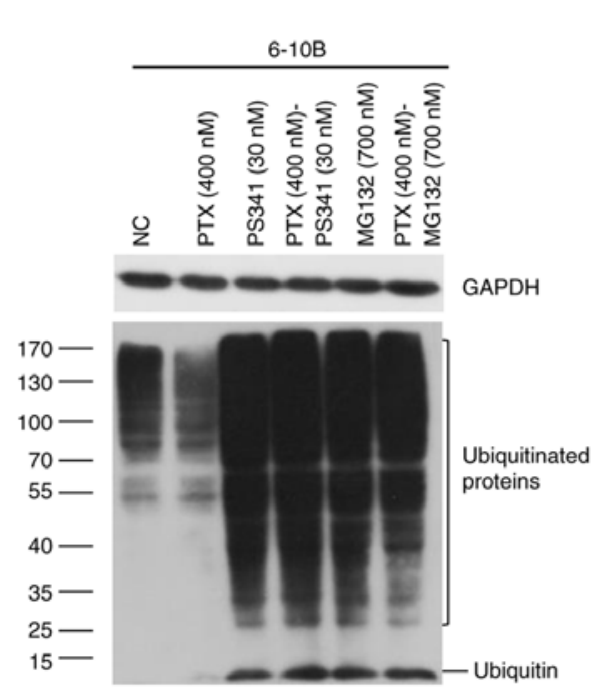

D

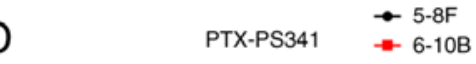

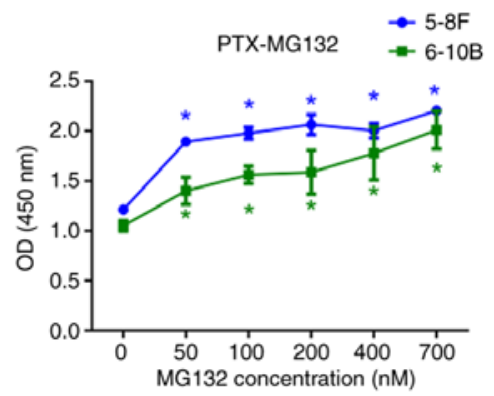

Figure 1. Proteasome inhibitors reduce the paclitaxel-specific inhibition of nasopharyngeal carcinoma cell proliferation. Cell Counting Kit-8 assays demonstrated that PS341 or MG132 significantly decreased the paclitaxel-induced inhibition of proliferation of (A) 5-8F and (B) 6-10B cells. The data are presented as the mean $\pm \mathrm{SD}(\mathrm{n}=3)$ and were analyzed using two-way ANOVA followed by Tukey's post hoc test. "P $<0.05$ vs. PTX (400 nM) group at $48 \mathrm{~h}$. (C) Western blot analysis revealed that PS341 $(30 \mathrm{nM})$ or MG132 $(700 \mathrm{nM})$ inhibited the functions of the proteasome in ubiquitinated protein degradation. (D) A gradual increase in the concentration of proteasome inhibitors PS341 (10-100 nM) and MG132 (50-700 nM) attenuated the inhibitory effect of paclitaxel (400 nM) on cell proliferation. The data are presented as the mean $\pm \mathrm{SD}(\mathrm{n}=3)$ and were analyzed using two-way ANOVA followed by Dunnett's post hoc test. ${ }^{*} \mathrm{P}<0.05$ vs. PTX (400 nM)-PS341/MG132 (0 nM) group. NC, negative control; OD, optical density; PS341, bortezomib; PTX, paclitaxel.

paclitaxel-treated NPC cells were blocked at M phase after 24 h. Compared with the NC group of 5-8F and 6-10B cells in Fig. 4B, the expression profile of cyclin-related proteins in the PTX (400 nM) group exhibited mitotic phase-specific features, such as low expression levels of cyclin E1 (during $\mathrm{G}_{1} / \mathrm{S}$ phase) and cyclin $\mathrm{A} 2$ (during $\mathrm{G}_{2} / \mathrm{M}$ transition), and high expression levels of aurora A and cyclin B1. Additionally, there was a reduction of CDK1 expression in the PTX (400 nM) group. On the other hand, the combination of paclitaxel and proteasome inhibitors restored cyclin E1 and cyclin A2 expression in the PTX (400 nM)-PS341 (30 nM) and PTX (400 nM)-MG132 $(700 \mathrm{nM})$ groups. The inhibition of proteasomes led to high expression levels of both CDK1 and cyclin B1 in proteasome inhibitor-treated groups [PS341 (30 nM),PTX (400 nM)-PS341 (30 nM), MG132 (700 nM) and PTX (400 nM)-MG132 (700 nM)] compared with the NC group (Fig. 4B). The contrast of the CDK1/cyclin B1 expression pattern between the PTX (400 nM) group (high cyclin B1 and low CDK1 expression compared with NC group) and proteasome inhibitor-treated groups (high cyclin B1 and high CDK1 expression compared with NC group) suggested that proteasome inhibitor-induced alterations in the CDK1/cyclin B1 expression pattern could be essential for escaping paclitaxel-induced mitotic arrest.

Proteasome inhibitors reduce paclitaxel-initiated cell death via CDK1/cyclin B1 signaling. Considering the onset time of 
A
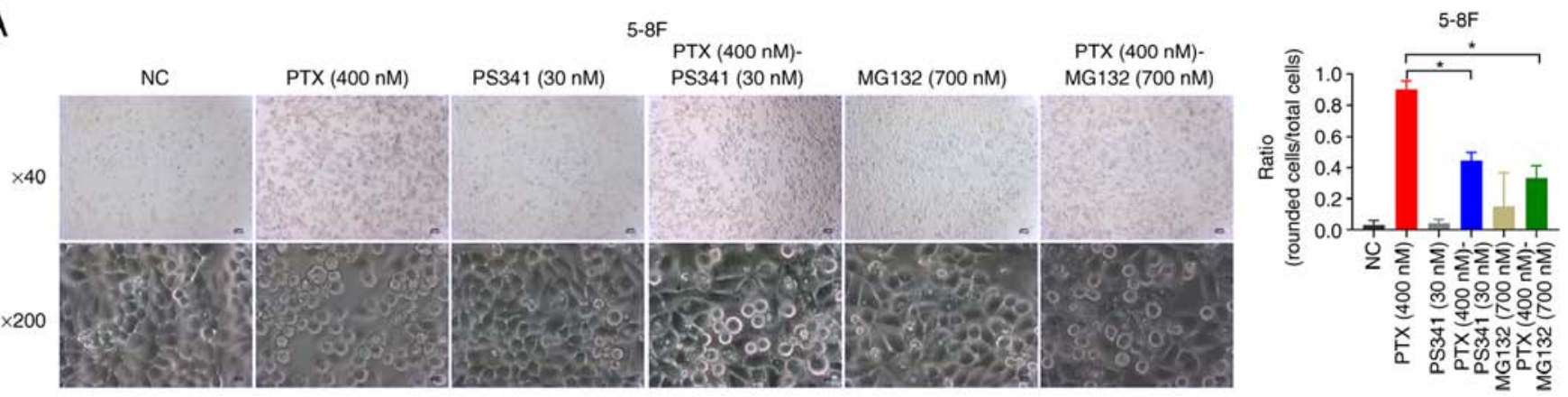

B
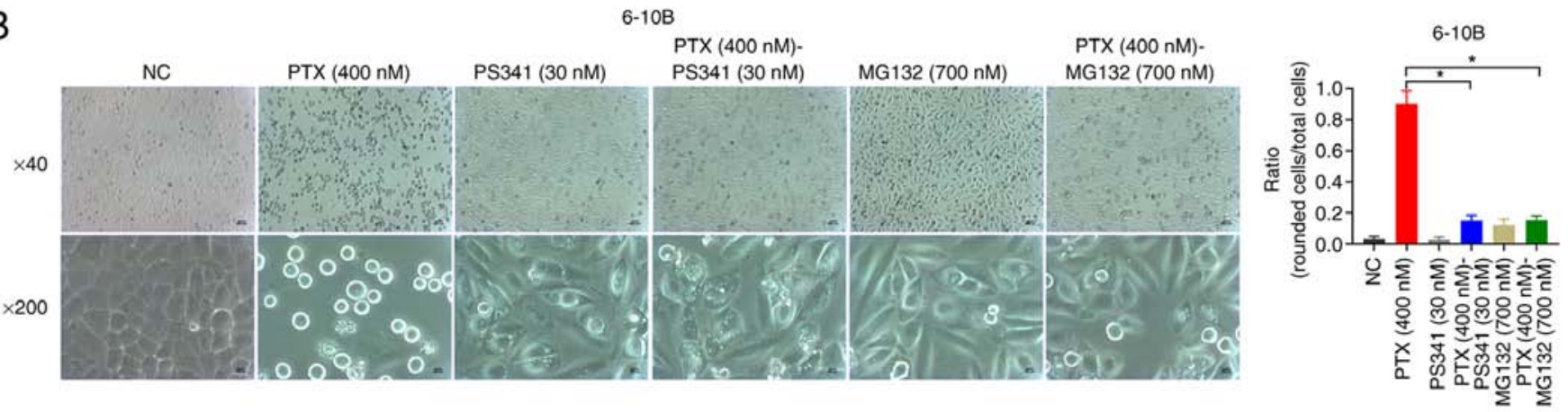

C

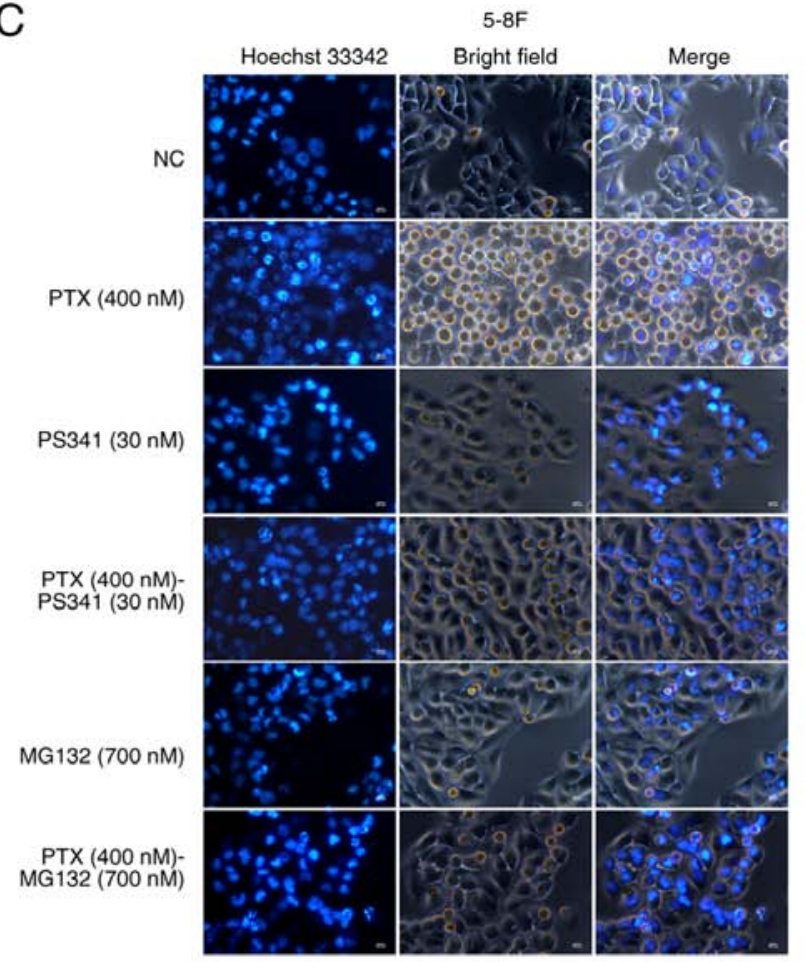

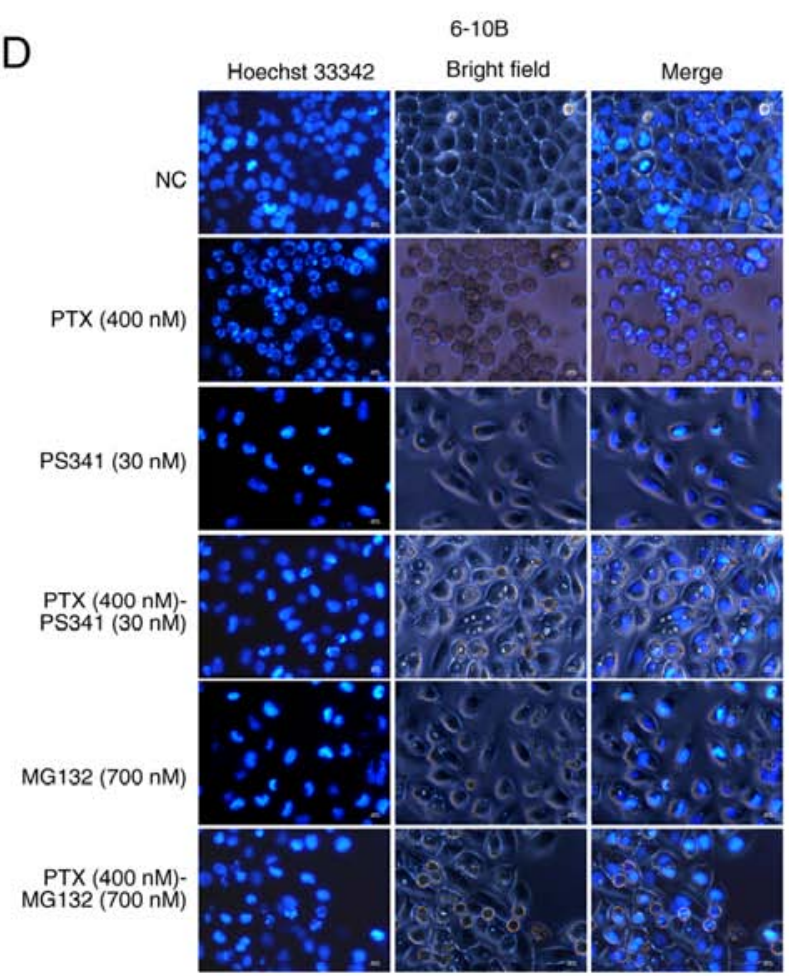

Figure 2. Proteasome inhibitors reduce paclitaxel-induced morphological changes and nuclear condensation in NPC cells. Proteasome inhibitors (PS341 and MG132) significantly reduced the paclitaxel-induced morphological changes of (A) 5-8F and (B) 6-10B cells. The data are presented as the mean \pm SD ( $\mathrm{n}=5$ ) and were analyzed using one-way ANOVA followed by Tukey's post hoc test. ${ }^{~} \mathrm{P}<0.05$. Magnification, $\mathrm{x} 40$; scale bar, $500 \mu \mathrm{m}$ (top row). Magnification, $\mathrm{x} 200$; scale bar, $100 \mu \mathrm{m}$ (bottom row). Proteasome inhibitors reduced nuclear condensation in rounded (C) 5-8F and (D) 6-10B cells. Magnification, x200; scale bar, $100 \mu \mathrm{m}$. NC, negative control; NPC, nasopharyngeal carcinoma; PS341, bortezomib; PTX, paclitaxel.

paclitaxel-initiated cell death and the key role of CDK1/cyclin B1 in mitosis regulation, the present study examined the expression profile of $\mathrm{CDK} 1 /$ cyclin $\mathrm{B} 1$ and its related proteins at 24 and $48 \mathrm{~h}$. In the paclitaxel-treated NPC cells, CDK1 was activated (compared with NC groups, T161 phosphorylation was increased and T14 phosphorylation was decreased) at
$24 \mathrm{~h}$, while cyclin B1 proteolysis and the caspase-9/PARP apoptosis cascade were activated at $48 \mathrm{~h}$. In the present study, p-CDK1 T161 separated into two bands: Band 1 reflected T161 phosphorylation combination with inhibitory phosphorylation of either T14 or Y15, whereas band 2 reflected the active single T161 phosphorylated form of CDK1. In the 
A

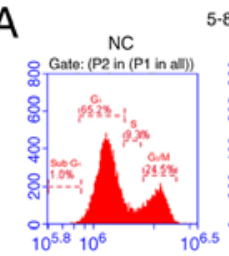

5-8F

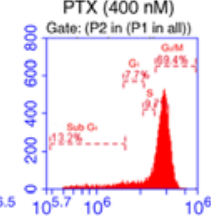

PTX $(400 \mathrm{nM})$ -
PS $341(30 \mathrm{nM})$

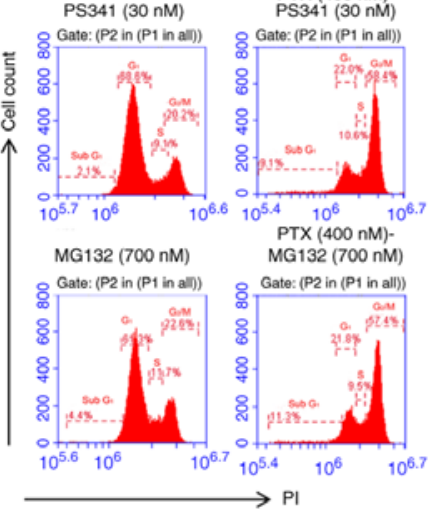

- NC

$-\mathrm{NTX}(400 \mathrm{nM})$
$=\mathrm{PS} 341(30 \mathrm{nM})$

- PTX (400 nM)-PS341 (30 nM) - $\mathrm{MG}$

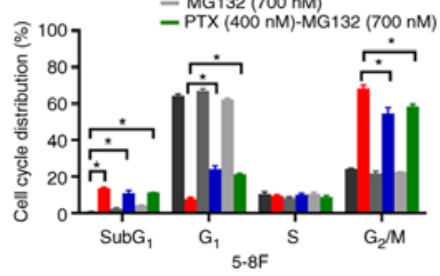

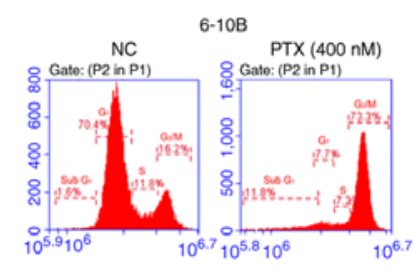

PTX $(400 \mathrm{nM})$ -

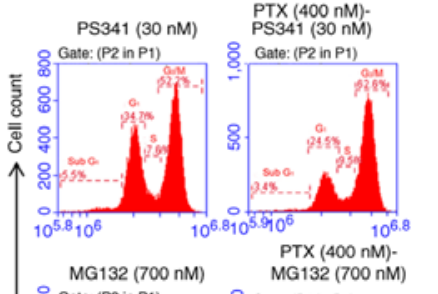
8 . Gate: (P2 in P1) \& Gate: (P2 in P1)
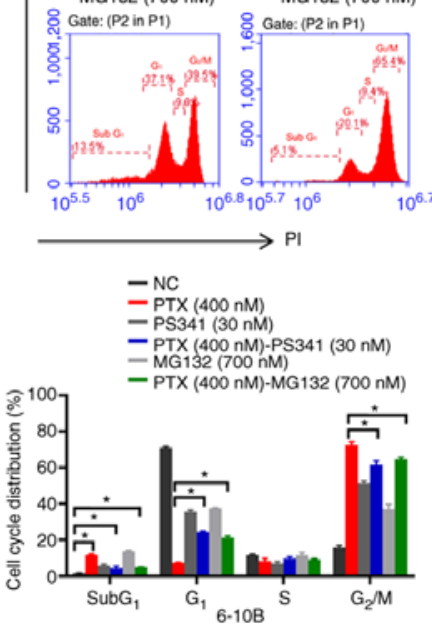

B

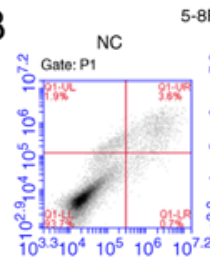

PTX (400 nM)

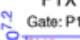

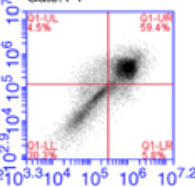

$\begin{array}{ll}\text { PS341 (30 nM) PTX (400 nM)- } & \text { PS341 (30 nM) }\end{array}$

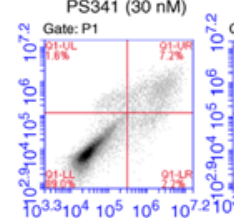

Gate: P1
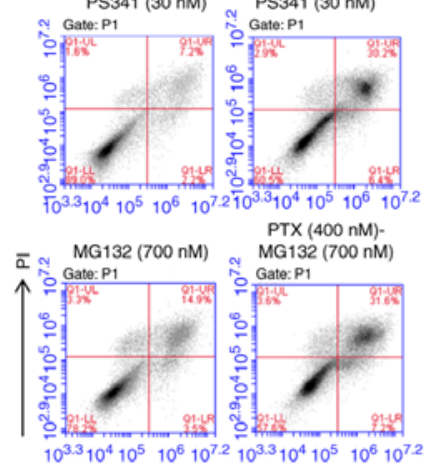

$10^{3.3} 10^{4} 10^{5} 10^{6} 10^{7.2} 10^{3.3} 10^{4} 10^{5} 10^{6} 10^{72}$

$\rightarrow$ Annexin V-FITC

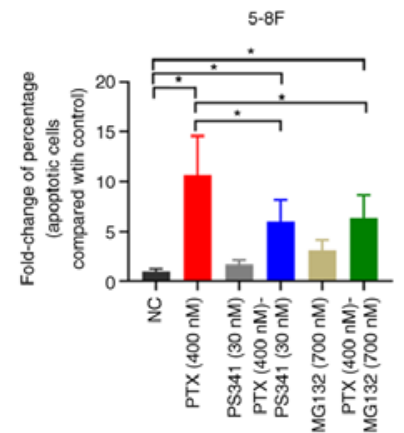

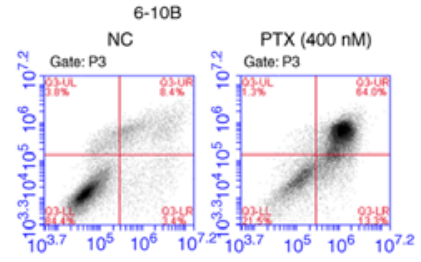

PTX (400 nM)-
PS 341 (30 nM)

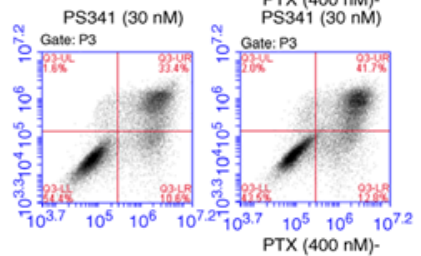

MG132 (700 nM)

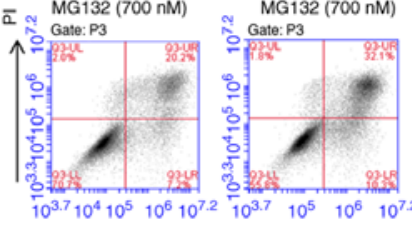

$\longrightarrow$ Annexin V-FITC

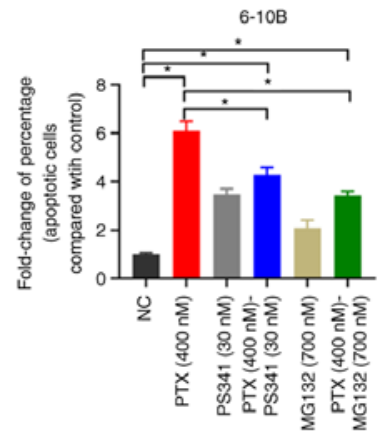

Figure 3. Proteasome inhibitors decrease paclitaxel-induced cell cycle arrest and apoptosis of nasopharyngeal carcinoma cells. (A) Proteasome inhibitors (PS341 and MG132) significantly reduced the paclitaxel-induced $\mathrm{G}_{2} / \mathrm{M}$ phase arrest at $24 \mathrm{~h}$. The data are presented as the mean \pm SD (n=3) and were analyzed using two-way ANOVA followed by Tukey's post hoc test. "P<0.05. (B) Proteasome inhibitors significantly reduced paclitaxel-induced apoptosis. The data are presented as the mean \pm SD $(n=3)$ and were analyzed using one-way ANOVA followed by Tukey's post hoc test. "P<0.05. NC, negative control; PS341, bortezomib; PTX, paclitaxel.

proteasome inhibitor-treated NPC cells, PS341 (30 nM), PTX (400 nM)-PS341 (30 nM), MG132 (700 nM) and PTX (400 nM)-MG132 (700 nM) groups sustained the high expression levels of CDK1/cyclin B1 proteins, and multi-band T161 phosphorylation status of CDK1. Multisite phosphorylation of CDK1 prevents its premature activation and demonstrates that the cells are distributed in a different phase of the cell cycle (28). Additionally, compared with paclitaxel-treated cells in the PTX (400 $\mathrm{nM})$ group, there was persistent high CDK1/cyclin B1 protein expression with MCL1 accumulation, less cleavage of caspase-9 and PARP in the PS341 (30 nM), PTX (400 nM)-PS341 (30 nM), MG132 (700 nM) and PTX (400 nM)-MG132 (700 nM) groups (Fig. 4C). Following culture with cycloheximide for $8 \mathrm{~h}$, PS341 was also associated with accumulation of cyclin B1 and MCL1 proteins in 5-8F and 6-10B cells at $24 \mathrm{~h}$ (Fig. S1).

InhibitionofCDK1 by Ro3306decreasesthepaclitaxel-induced mitotic catastrophe. Ro3306, a potent and selective inhibitor of CDK1 (36), also decreased paclitaxel-induced mitotic catastrophe and cell death in NPC cells in the present study. When the cells were treated with paclitaxel and Ro3306, compared with the PTX (400 nM) group, the optical density results of the CCK- 8 assay at $48 \mathrm{~h}$ were significantly increased in the PTX (400 nM)-Ro3306 (5 $\mu \mathrm{M})$ group (Fig. 5A), there was a decreased paclitaxel-specific inhibition of cell proliferation. In apoptotic cell detection, compared with the NC group, the addition of paclitaxel in the PTX (400 nM) and PTX (400 $\mathrm{nM})$-Ro3306 $(5 \mu \mathrm{M})$ groups increased the percentage of apoptotic cells (Figs. 5B and S2). When the cells were treated with paclitaxel and Ro3306, compared with PTX (400 $\mathrm{nM}$ ) group, the paclitaxel-induced apoptosis in the PTX (400 nM)-Ro3306 (5 $\mu \mathrm{M})$ group was decreased (Figs. 5B and S2). In addition, western blotting results indicated that Ro3306 decreased the paclitaxel-induced apoptosis signaling via the MCL1/caspase-9/PARP signaling pathway (Fig. 5C). Therefore, loss of paclitaxel lethality may be due to the inhibition of CDK1.

\section{Discussion}

A combination of drugs with different mechanisms presents an alternative and effective strategy in enhancing cancer therapeutic effects. For instance, in paclitaxel-resistant ovarian cancer, PS341 restores paclitaxel-induced cell death by alteration of microtubule dynamics and hedgehog signaling (37). 
A
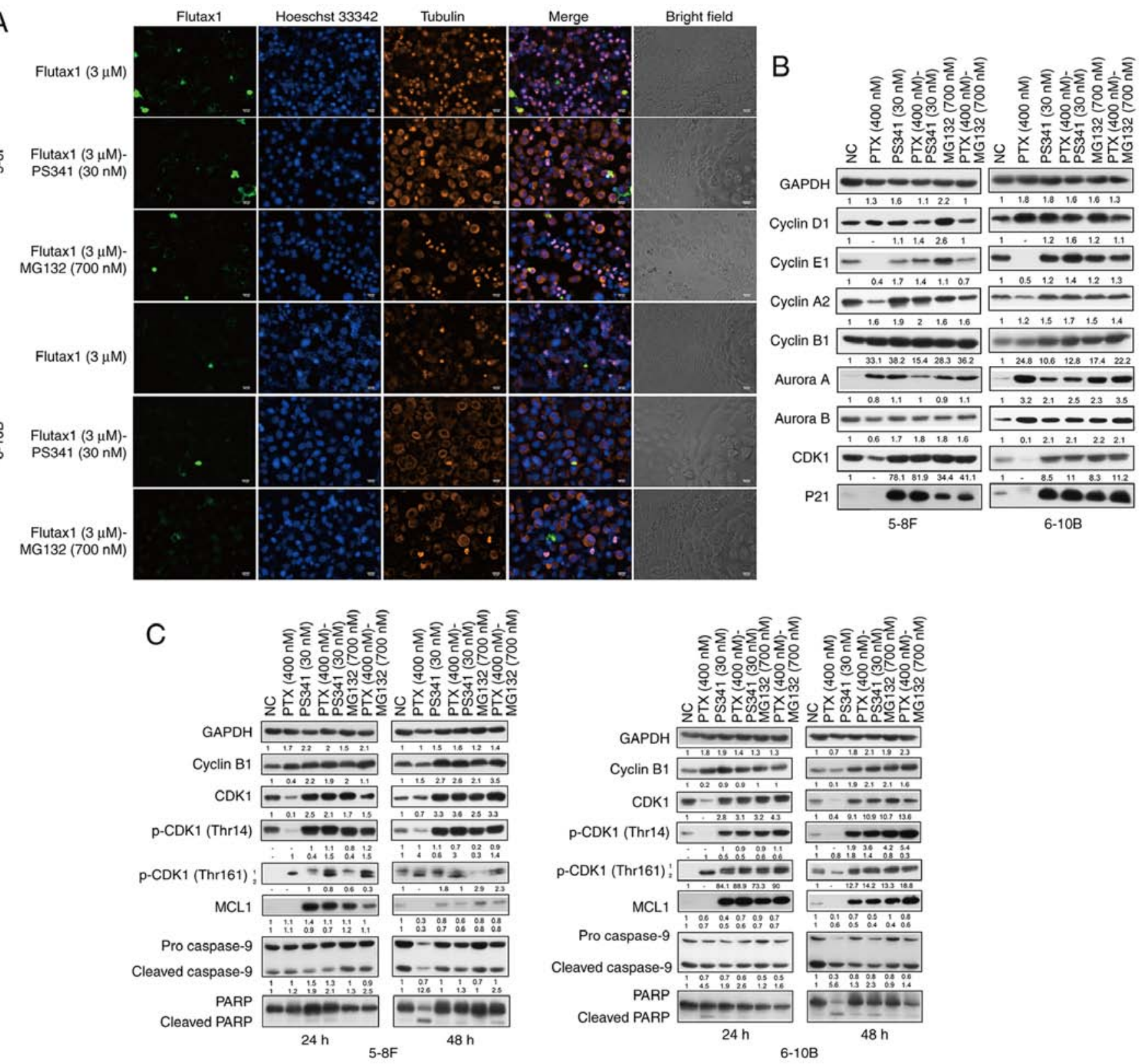

Figure 4. Proteasome inhibitors perturb CDK1/cyclin B1 functions in regulating the NPC cell cycle. (A) Proteasome inhibitor-treated NPC cells were freed from nuclear condensation induced by flutax1 and had an enlarged microtubule cytoskeleton system. Magnification, x200; scale bar, $100 \mu \mathrm{m}$. (B) NPC cells treated with the proteasome inhibitors presented a different cell cycle proteins profile compared with the paclitaxel-treated cells at $24 \mathrm{~h}$, particularly in terms of CDK1 and cyclin B1. (C) Proteasome inhibitors altered the expression profile of CDK1/cyclin B1 and decreased paclitaxel-induced apoptosis through MCL1 accumulation and caspase-9 stabilization at 24 and $48 \mathrm{~h}$. Representative western blotting results from three independent experiments. Grayscale semi-quantification of bands was performed using ImageJ software. Control group was normalized to 1. Data are presented as fold change in protein expression relative to the control group. No protein detected was marked as '-'. MCL1, MCL1 apoptosis regulator, BCL2 family member; NC, negative control; NPC, nasopharyngeal carcinoma; p-, phosphorylated; PARP, poly (ADP-ribose) polymerase; PS341, bortezomib; PTX, paclitaxel.

Furthermore, in H-ras-dependent paclitaxel-resistant epithelial solid tumors, PS341 blocks Bcl-2-like protein 11 (BIM) degradation and restores BIM-dependent apoptosis associated with paclitaxel treatment (38). Therefore, the combination of paclitaxel with PS341 appears to be a promising tumor chemotherapeutic alternative in overcoming paclitaxel-resistance. While a previous clinical trial associated the use of PS341 with striking toxicity and limited clinical benefit in solid tumors (39-42), the drug is recommended in refractory advanced solid tumors and unresectable stage III non-small-cell lung cancer (43-46). Therefore, more trials are required to further dissect the effects of the use of PS341 with paclitaxel.
In antimitotic drug-induced prolonged mitotic arrest of cells, CDK1/cyclin B1 can be regarded as a hinge between survival and death (47). Stabilization and persistent activation of CDK1/cyclin B1 maintains cells in the mitosis phase (48). Rapid degradation of cyclin B1 and inactivation of CDK1 promote cell death pathways with accumulation of death activators and loss of death inhibitors (49). For example, caspase-9 and MCL1 are typical apoptosis and anti-apoptosis proteins, respectively, regulated by CDK1 $(50,51)$. CDK1 phosphorylates caspase- 9 at an inhibitory site to prevent caspase- 9 cleavage, while phosphorylation of MCL1 at the T92 site triggers its degradation $(50,51)$. During paclitaxel-induced mitotic arrest, 
A

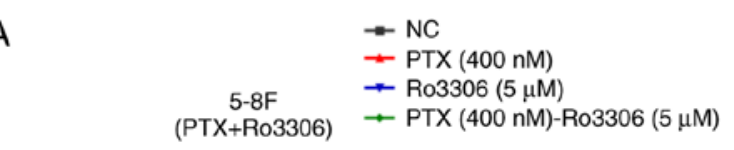

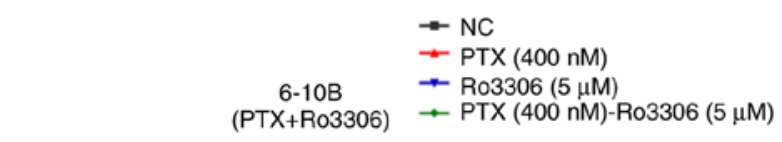
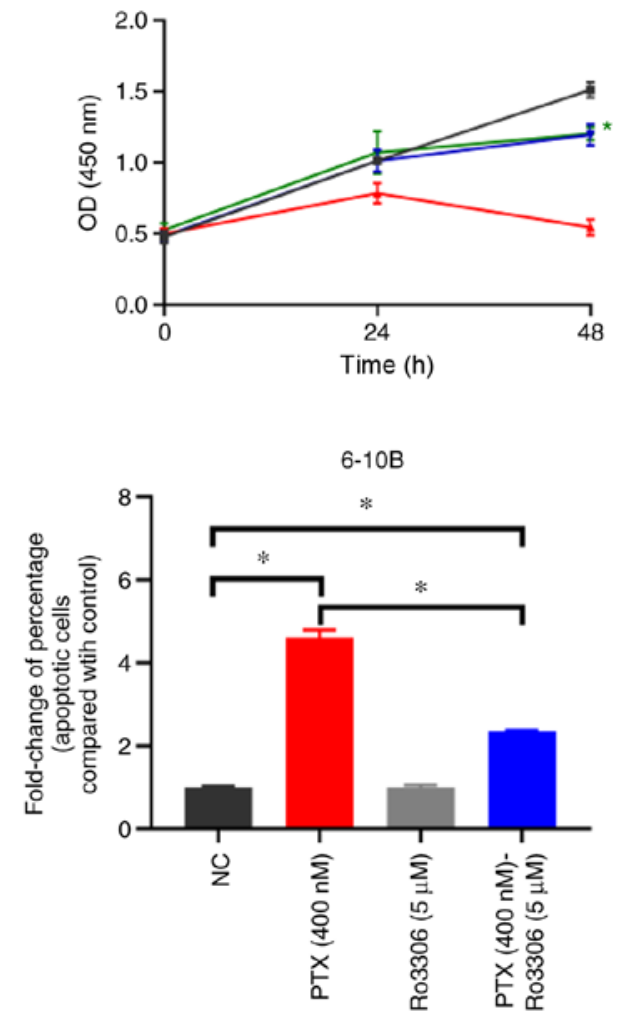
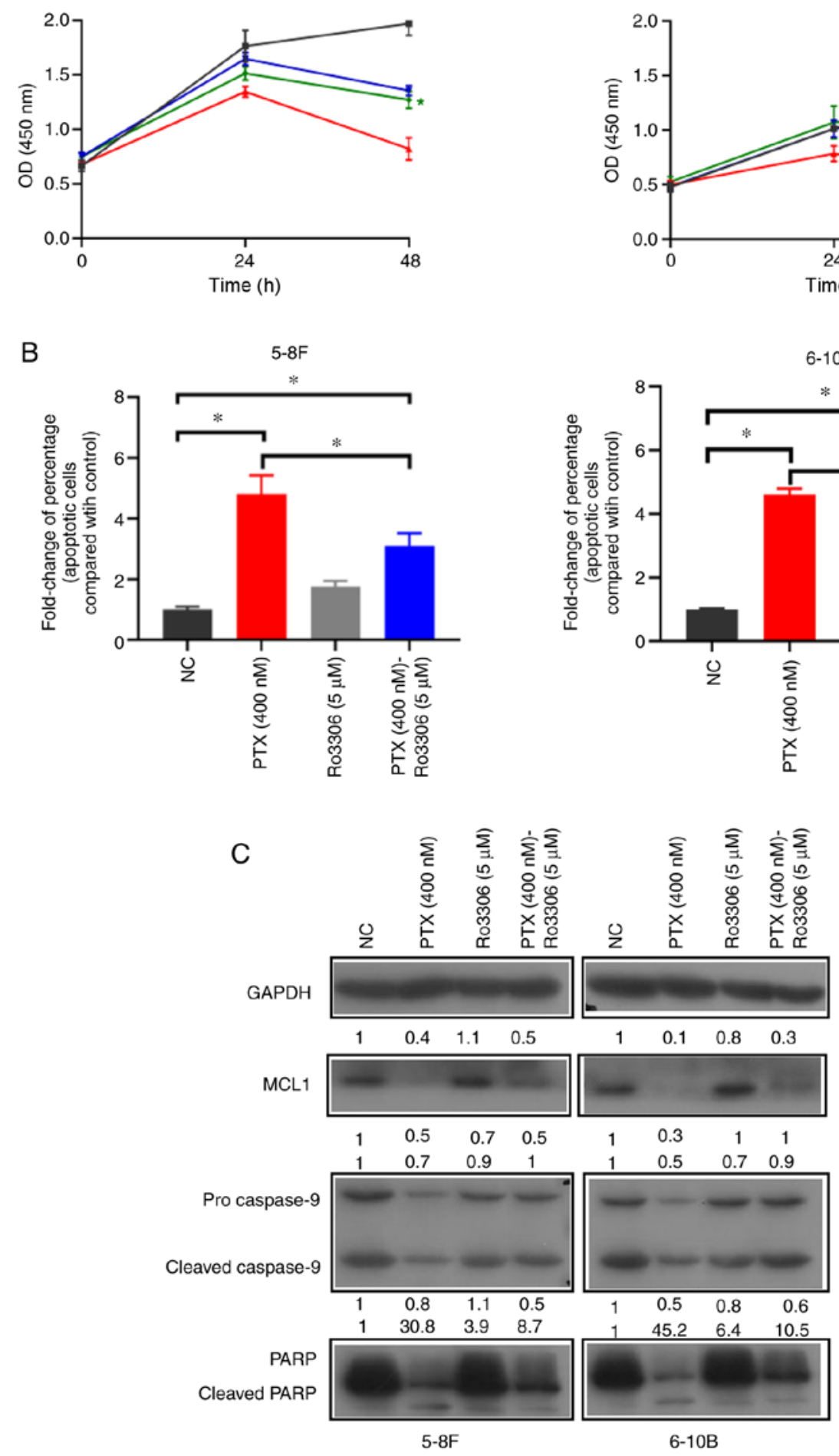

Figure 5. Ro3306 decreases paclitaxel-induced mitotic catastrophe in nasopharyngeal carcinoma cells. (A) Cell Counting Kit-8 assays illustrated that Ro3306 decreased paclitaxel-induced inhibition of proliferation of $5-8 \mathrm{~F}$ and $6-10 \mathrm{~B}$ cells. The data are presented as the mean \pm SD ( $\mathrm{n}=3$ ) and were analyzed using two-way ANOVA followed by Tukey's post hoc test. "P<0.05 vs. PTX (400 nM) group. (B) Ro3306 significantly reduced paclitaxel-induced apoptosis. The data are presented as the mean $\pm \mathrm{SD}(\mathrm{n}=3)$ and were analyzed using one-way ANOVA followed by Tukey's post hoc test. ${ }^{*} \mathrm{P}<0.05$. $(\mathrm{C}) \mathrm{Ro3306}$ decreased paclitaxel-induced MCL1 proteolysis and caspase-9/PARP cleavage. Representative western blotting results from three independent experiments. Grayscale semi-quantification of bands was performed using ImageJ software. Control group was normalized to 1. Data are presented as fold change in protein expression relative to the control group. No protein detected was marked as '-'. MCL1, MCL1 apoptosis regulator, BCL2 family member; NC, negative control; OD, optical density; PARP, poly (ADP-ribose) polymerase; PTX, paclitaxel.

rapid degradation of cyclin $\mathrm{B} 1$ activates death signals, such as MCL1 hydrolysis and the cleavage of caspase-9 (52).
The present results demonstrated that nontoxic concentrations of proteasome inhibitors and CDK1 inhibitor RO3306 
decreased the paclitaxel-induced mitotic death in NPC cells. It was hypothesized that the perturbed CDK1/cyclin B1 balance in mitosis could be defining the reduced mitotic death. Additionally, when restraining CDK1/cyclin B1 destruction via blockage of the ubiquitin-proteasome pathway, the side-effect of proteasome inhibition could further lead to accumulation of $\mathrm{p} 21^{\text {Waf1/Cip1 }}$ and MCL1 $(53,54)$. P21 $1^{\text {Waf1/Cip1 }}$ can interact with CDK1 and inhibits its function (55). Accumulation of MCL1 was associated with higher anti-apoptotic signaling (52), and this side-effect of proteasome inhibitors may have enhanced the suppression in CDK1/cyclin B1-triggered cell death. Therefore, it was hypothesized that the mechanism of proteasome inhibitors in disturbing CDK1 function is more complex and stronger than that of RO3306. Whereas the CDK1/cyclin B1 catalytic activity defines the mitosis-promoting factor, data on its role in mitosis remains insufficient. Additionally, data on when and how rapidly CDK1/cyclin B1 is activated in mammalian cells, as well as reorganization of the cell as it enters and exits mitosis is limited $(56,57)$.

The present study demonstrated that NPC cells treated with nontoxic doses of proteasome inhibitors block proliferation without CDK1/cyclin B1 extinction. Combined with previous data $(58,59)$, it was suggested that CDK1/cyclin B1 could be more closely associated with the regulation of apoptosis compared with cell reproduction. CDK1/cyclin B1 functions as a rate-limiting regulator but is not essential for mitotic entry and progression in mammalian somatic cells (60). It was hypothesized that the side-effect of proteasome inhibitors could be vital in cell cycle-related research, especially in cell cycle regulation and anti-mitotic drug resistance.

In conclusion, the present study demonstrated that the abnormal accumulation of CDK1/cyclin B1 protein could be mediating the suppressed effects of paclitaxel when used in combination with proteasome inhibitors. Therefore, increased caution is required when using a combination of paclitaxel with proteasome or CDK1 inhibitors in the treatment of NPC.

\section{Acknowledgements}

Not applicable.

\section{Funding}

The present study was supported by the National Natural Science Foundation of China (grant no. 81802952), the Natural Science Foundation of Hunan Province (grant no. 2020JJ5608), the Scientific Research Funds of Health Commission of Hunan Province (grant no. B2019141), and the Science and Technology Program Foundation of Changsha (grant no. kq1901017).

\section{Availability of data and materials}

The datasets used and/or analyzed during the current study are available from the corresponding author on reasonable request.

\section{Authors' contributions}

LH, XP, HZ and BJ performed the experiments. XL and MJ analyzed the data. $\mathrm{JH}$ conducted literature search and data interpretation. BJ drafted the initial manuscript. BJ and $\mathrm{JH}$ confirm the authenticity of all the raw data. BJ designed and supervised the study. All authors read and approved the final manuscript.

\section{Ethics approval and consent to participate}

Not applicable.

\section{Patient consent for publication}

Not applicable.

\section{Competing interests}

The authors declare that they have no competing interests.

\section{References}

1. Chen YP, Chan ATC, Le QT, Blanchard P, Sun Y and Ma J: Nasopharyngeal carcinoma. Lancet 394: 64-80, 2019.

2. Ji MF, Sheng W, Cheng WM, Ng MH, Wu BH, Yu X, Wei KR, Li FG, Lian SF, Wang PP, et al: Incidence and mortality of nasopharyngeal carcinoma: Interim analysis of a cluster randomized controlled screening trial (PRO-NPC-001) in southern China. Ann Oncol 30: 1630-1637, 2019.

3. Vasan N, Baselga J and Hyman DM: A view on drug resistance in cancer. Nature 575: 299-309, 2019.

4. Kaidar-Person O, Gil Z and Billan S: Precision medicine in head and neck cancer. Drug Resist Updat 40: 13-16, 2018.

5. Madani Tonekaboni SA, Soltan Ghoraie L, Manem VSK and Haibe-Kains B: Predictive approaches for drug combination discovery in cancer. Brief Bioinform 19: 263-276, 2018.

6. Wong AS, Soo RA, Lu JJ, Loh KS, Tan KS, Hsieh WS, Shakespeare TP, Chua ET, Lim HL and Goh BC: Paclitaxel, 5-fluorouracil and hydroxyurea concurrent with radiation in locally advanced nasopharyngeal carcinoma. Ann Oncol 17: 1152-1157, 2006.

7. Scott K, Hayden PJ, Will A, Wheatley K and Coyne I: Bortezomib for the treatment of multiple myeloma. Cochrane Database Syst Rev 4: CD010816, 2016

8. Davies AM, Lara PN Jr, Mack PC and Gandara DR: Incorporating bortezomib into the treatment of lung cancer. Clin Cancer Res 13: s4647-4651, 2007.

9. Huang IT, Dhungel B, Shrestha R, Bridle KR, Crawford DHG, Jayachandran A and Steel JC: Spotlight on Bortezomib: Potential in the treatment of hepatocellular carcinoma. Expert Opin Investig Drugs 28: 7-18, 2019.

10. Ri M: Endoplasmic-reticulum stress pathway-associated mechanisms of action of proteasome inhibitors in multiple myeloma. Int J Hematol 104: 273-280, 2016.

11. Manasanch EE and Orlowski RZ: Proteasome inhibitors in cancer therapy. Nat Rev Clin Oncol 14: 417-433, 2017.

12. Hochstrasser M: Ubiquitin, proteasomes, and the regulation of intracellular protein degradation. Curr Opin Cell Biol 7: 215-223, 1995.

13. Skaar JR and Pagano M: Control of cell growth by the SCF and APC/C ubiquitin ligases. Curr Opin Cell Biol 21: 816-824, 2009.

14. Joerger M: Treatment regimens of classical and newer taxanes. Cancer Chemother Pharmacol 77: 221-233, 2016.

15. Alushin GM, Lander GC, Kellogg EH, Zhang R, Baker D and Nogales E: High-resolution microtubule structures reveal the structural transitions in alphabeta-tubulin upon GTP hydrolysis. Cell 157: 1117-1129, 2014.

16. Weaver BA: How Taxol/paclitaxel kills cancer cells. Mol Biol Cell 25: 2677-2681, 2014.

17. Shi $X$ and Sun $X$ : Regulation of paclitaxel activity by microtubule-associated proteins in cancer chemotherapy. Cancer Chemother Pharmacol 80: 909-917, 2017.

18. Vitale I, Galluzzi L, Castedo M and Kroemer G: Mitotic catastrophe: A mechanism for avoiding genomic instability. Nat Rev Mol Cell Biol 12: 385-392, 2011.

19. Roninson IB, Broude EV and Chang BD: If not apoptosis, then what? Treatment-induced senescence and mitotic catastrophe in tumor cells. Drug Resist Updat 4: 303-313, 2001. 
20. Castedo M, Perfettini JL, Roumier T, Andreau K, Medema R and Kroemer G: Cell death by mitotic catastrophe: A molecular definition. Oncogene 23: 2825-2837, 2004.

21. Denisenko TV, Sorokina IV, Gogvadze V and Zhivotovsky B: Mitotic catastrophe and cancer drug resistance: A link that must to be broken. Drug Resist Updat 24: 1-12, 2016.

22. Shi J and Mitchison TJ: Cell death response to anti-mitotic drug treatment in cell culture, mouse tumor model and the clinic. Endocr Relat Cancer 24: T83-T96, 2017.

23. Brito DA and Rieder CL: Mitotic checkpoint slippage in humans occurs via cyclin B destruction in the presence of an active checkpoint. Curr Biol 16: 1194-1200, 2006.

24. Mc Gee MM: Targeting the mitotic catastrophe signaling pathway in cancer. Mediators Inflamm 2015: 146282, 2015.

25. Fung TK and Poon RY: A roller coaster ride with the mitotic cyclins. Semin Cell Dev Biol 16: 335-342, 2005.

26. Kalous J, Jansova D and Susor A: Role of cyclin-dependent kinase 1 in translational regulation in the M-Phase. Cells 9: 1568 2020.

27. Yang J, Bardes ES, Moore JD, Brennan J, Powers MA and Kornbluth S: Control of cyclin B1 localization through regulated binding of the nuclear export factor CRM1. Genes Dev 12 2131-2143, 1998

28. Coulonval K, Kooken H and Roger PP: Coupling of T161 and T14 phosphorylations protects cyclin B-CDK1 from premature activation. Mol Biol Cell 22: 3971-3985, 2011.

29. Lindqvist A, Rodriguez-Bravo V and Medema RH: The decision to enter mitosis: Feedback and redundancy in the mitotic entry network. J Cell Biol 185: 193-202, 2009.

30. Sinha D, Duijf PHG and Khanna KK: Mitotic slippage: An old tale with a new twist. Cell cycle 18: 7-15, 2019.

31. Mascaraque M, Delgado-Wicke P, Damian A, Lucena SR, Carrasco E and Juarranz A: Mitotic catastrophe induced in HeLa tumor cells by photodynamic therapy with methyl-aminolevulinate. Int J Mol Sci 20: 1229, 2019.

32. Vakifahmetoglu H, Olsson M and Zhivotovsky B: Death through a tragedy: Mitotic catastrophe. Cell Death Differ 15: 1153-1162, 2008

33. Orth JD, Kohler RH, Foijer F, Sorger PK, Weissleder R and Mitchison TJ: Analysis of mitosis and antimitotic drug responses in tumors by in vivo microscopy and single-cell pharmacodynamics. Cancer Res 71: 4608-4616, 2011.

34. Jackman M, Kubota Y, den Elzen N, Hagting A and Pines J: Cyclin A- and cyclin E-Cdk complexes shuttle between the nucleus and the cytoplasm. Mol Biol Cell 13: 1030-1045, 2002.

35. Harashima H, Dissmeyer N and Schnittger A: Cell cycle control across the eukaryotic kingdom. Trends Cell Biol 23: 345-356, 2013.

36. Vassilev LT, Tovar C, Chen S, Knezevic D, Zhao X, Sun H, Heimbrook DC and Chen L: Selective small-molecule inhibitor reveals critical mitotic functions of human CDK1. Proc Nat Acad Sci USA 103: 10660-10665, 2006.

37. Steg AD, Burke MR, Amm HM, Katre AA, Dobbin ZC, Jeong DH and Landen CN: Proteasome inhibition reverses hedgehog inhibitor and taxane resistance in ovarian cancer. Oncotarget 5: 7065-7080, 2014.

38. Tan TT, Degenhardt K, Nelson DA, Beaudoin B, Nieves-Neira W, Bouillet P, Villunger A, Adams JM and White E: Key roles of BIM-driven apoptosis in epithelial tumors and rational chemotherapy. Cancer Cell 7: 227-238, 2005

39. Edelman MJ, Burrows W, Krasna MJ, Bedor M, Smith R and Suntharalingam M: Phase I trial of carboplatin/paclitaxel/bortezomib and concurrent radiotherapy followed by surgical resection in Stage III non-small cell lung cancer. Lung cancer 68: 84-88, 2010.

40. Jatoi A, Dakhil SR, Foster NR, Ma C, Rowland KM Jr, Moore DF Jr, Jaslowski AJ, Thomas SP, Hauge MD, Flynn PJ, et al: Bortezomib, paclitaxel, and carboplatin as a first-line regimen for patients with metastatic esophageal, gastric, and gastroesophageal cancer: Phase II results from the North Central Cancer Treatment Group (N044B). J Thorac Oncol 3: 516-520, 2008

41. Croghan GA, Suman VJ, Maples WJ, Albertini M, Linette G, Flaherty L, Eckardt J, Ma C, Markovic SN and Erlichman C: A study of paclitaxel, carboplatin, and bortezomib in the treatment of metastatic malignant melanoma: A phase 2 consortium study. Cancer 116: 3463-3468, 2010.
42. Cresta S, Sessa C, Catapano CV, Gallerani E, Passalacqua D, Rinaldi A, Bertoni F, Vigano L, Maur M, Capri G, et al: Phase I study of bortezomib with weekly paclitaxel in patients with advanced solid tumours. Eur J Cancer 44: 1829-1834, 2008

43. Mehnert JM, Tan AR, Moss R, Poplin E, Stein MN, Sovak M, Levinson K, Lin H, Kane M, Gounder M, et al: Rationally designed treatment for solid tumors with MAPK pathway activation: A phase I study of paclitaxel and bortezomib using an adaptive dose-finding approach. Mol Cancer Ther 10: 1509-1519, 2011.

44. Ramaswamy B,Bekaii-Saab T, Schaaf LJ, Lesinski GB, Lucas DM, Young DC, Ruppert AS, Byrd JC, Culler K, Wilkins D, et al: A dose-finding and pharmacodynamic study of bortezomib in combination with weekly paclitaxel in patients with advanced solid tumors. Cancer Chemother Pharmacol 66: 151-158, 2010.

45. Zhao Y, Foster NR, Meyers JP, Thomas SP, Northfelt DW, Rowland KM Jr, Mattar BI, Johnson DB, Molina JR, Mandrekar SJ, et al: A phase I/II study of bortezomib in combination with paclitaxel, carboplatin, and concurrent thoracic radiation therapy for non-small-cell lung cancer: North Central Cancer Treatment Group (NCCTG)-N0321. J Thorac Oncol 10: $172-180,2015$

46. Ma C, Mandrekar SJ, Alberts SR, Croghan GA, Jatoi A, Reid JM, Hanson LJ, Bruzek L, Tan AD, Pitot HC, et al: A phase I and pharmacologic study of sequences of the proteasome inhibitor, bortezomib (PS-341, Velcade), in combination with paclitaxel and carboplatin in patients with advanced malignancies. Cancer Chemother Pharmacol 59: 207-215, 2007.

47. Castedo M, Perfettini JL, Roumier T and Kroemer G Cyclin-dependent kinase-1: Linking apoptosis to cell cycle and mitotic catastrophe. Cell Death Differ 9: 1287-1293, 2002.

48. Sakurikar N, Eichhorn JM and Chambers TC: Cyclin-dependent kinase-1 (Cdk1)/cyclin B1 dictates cell fate after mitotic arrest via phosphoregulation of antiapoptotic $\mathrm{Bcl}-2$ proteins. J Biol Chem 287: 39193-39204, 2012.

49. Hou Y, Allan LA and Clarke PR: Phosphorylation of XIAP by CDK1-cyclin-B1 controls mitotic cell death. J Cell Sci 130: 502-511, 2017.

50. Harley ME, Allan LA, Sanderson HS and Clarke PR Phosphorylation of Mcl-1 by CDK1-cyclin B1 initiates its Cdc20-dependent destruction during mitotic arrest. The EMBO J 29: 2407-2420, 2010.

51. Allan LA and Clarke PR: Phosphorylation of caspase-9 by CDK1/cyclin B1 protects mitotic cells against apoptosis. Mol Cell 26: 301-310, 2007.

52. Clarke PR and Allan LA: Destruction's our delight: Controlling apoptosis during mitotic arrest. Cell Cycle 9: 4035-4036, 2010.

53. Lu Z and Hunter T: Ubiquitylation and proteasomal degradation of the p21(Cip1), p27(Kip1) and p57(Kip2) CDK inhibitors. Cell Cycle 9: 2342-2352, 2010

54. Millman SE and Pagano M: MCL1 meets its end during mitotic arrest. EMBO Rep 12: 384-385, 2011.

55. Kreis NN, Louwen F and Yuan J: Less understood issues: p21(Cip1) in mitosis and its therapeutic potential. Oncogene 34: $1758-1767,2015$

56. Gavet O and Pines J: Progressive activation of CyclinB1-Cdk1 coordinates entry to mitosis. Dev Cell 18: 533-543, 2010.

57. Rata S, Suarez Peredo Rodriguez MF, Joseph S, Peter N, Echegaray Iturra F, Yang F, Madzvamuse A, Ruppert JG, Samejima K, Platani M, et al: Two interlinked bistable switches govern mitotic control in mammalian cells. Curr Biol 28: 3824-3832 e3826, 2018

58. Diril MK, Ratnacaram CK, Padmakumar VC, Du T, Wasser M, Coppola V, Tessarollo L and Kaldis P: Cyclin-dependent kinase 1 (Cdk1) is essential for cell division and suppression of DNA re-replication but not for liver regeneration. Proc Natl Acad Sci USA 109: 3826-3831, 2012.

59. Saito M, Mulati M, Talib SZ, Kaldis P, Takeda S, Okawa A and Inose H: The indispensable role of cyclin-dependent kinase 1 in skeletal development. Sci Rep 6: 20622, 2016.

60. Soni DV, Sramkoski RM, Lam M, Stefan T and Jacobberger JW: Cyclin B1 is rate limiting but not essential for mitotic entry and progression in mammalian somatic cells. Cell Cycle 7: 1285-1300, 2008.

This work is licensed under a Creative Commons Attribution-NonCommercial-NoDerivatives 4.0 International (CC BY-NC-ND 4.0) License. 